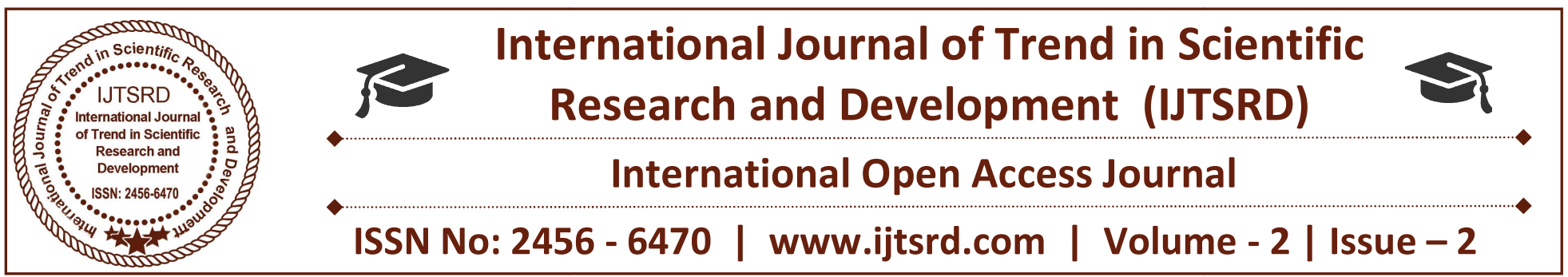

\title{
Consciousness: Role of Socio-Religious Reformative Movements in Kashmir (1846-1952)
}

\author{
Dr Syed Damsaz Ali Andrabi \\ College Teacher, History, Department of Higher Education, Jammu \& Kashmir, India
}

\section{ABSTRACT}

Freedom is one of the basic need without which a living organism cannot develop properly. Human beings, plants and animals all struggle for freedom if kept under restrictions in any way, because it is in their nature to remain free. From the very beginning when man was born, he started his struggle for freedom because he found that he could not do whatever he wished. The forces of nature thwarted him, therefore he fought against them with the basic idea of change and development. In comparison to animals man is bestowed with reason, logic, objectivity and he could retain events in memory and draw inferences from them for his own guidance. As a result of long experiences and constant struggle he was successful to a great extent in facing the mysteries of the nature and defending himself against her vagaries. It was this long drawn struggle that ultimately resulted in the birth of reformative movements with an objective to free themselves (Kashmiris) from the oppression of Dogras. They succeeded in their mission only when they got united under the broader banner of National Conference. As the name suggests it looks like political organisation but in real the voice of people got proper direction and shape.

Keywords: Religion, Peace, Behaviour, Ruling Section, Freedom, Commoners

\section{INTRODUCTION}

The people of Kashmir valley after realizing the nature of Dogra rulers were ultimately forced by the circumstances to fight the autocracy of Dogras in order to liberate themselves from the screws of oppression. No doubt a number of agreements and treaties were signed for the benefit of commoners. One such treaty of its kind was the treaty of Amritsar on $16^{\text {th }}$ March 1846 .The transfer of Kashmir to Maharaja Gulab Singh and to the male heirs of his body in lieu of seventy five lakhs of rupees by the British in 1846 through the treaty of Amritsar has made a complete watershed in the history of Kashmir. The treaty of Amritsar was not an exception to the general policy according to which the government of India conducted its relation with other native states of India at that time. During this period the relations between the native states and the British Indian government were conducted under the policy of subordinate isolation (1813-1858). This policy had two important features, firstly the foreign policy of these states was subordinated to British paramountcy in order to avoid any possible threat of the united front against the British authority. Secondly the rulers of these states were given a free hand in their internal affairs. Not only this theywere also assured of protection against the internal revolts and external aggressions.

After taking over as the ruler of the state, Maharaja Gulab Singh claimed to be an absolute sovereign. Moreover, he considered the state especially the valley of Kashmir as his personal purchased property. His successors also carried on both of these claims. But a thorough evaluation of the treaty of Amristsar and the subsequent development in the political history of Kashmir makes it amply clear that he was neither an absolute sovereign nor the sole proprietor 
of the state. Both of these claims were most probably aimed at legitimating their policy of rack- renting and sucking blood of working classes. A sort of imperialism developed in the state in which only Dogras were elevated to the position of masters and all non-Dogra communities and classes were given the identity of inferiors. The people of the valley were thus brought under the harsh rule of Dogras and they themselves were functioning as a vassal of the British. Although Dogra imperialism brought nothing positive but misery, physical and mental deterioration in its wake. By coming under the British suzerainty the valley began to have the impact of western ideas and modern civilization which finally awakened the people to demand their birth- right of independence.

\section{Though Maharaja Gulab Singh (d.1857) was} apparently on good terms with the British but side by side was also against any Western penetration in Kashmir. At his request special order was issued in 1854 by the Governor General Lord Dalhousie forbidding European visitors to remain in Kashmir during the winter. He established a rule that European were to be admitted to Srinagar by prescribed routes only and from the time of their entrance to their exit they were to be under vigilant supervision and were not to be allowed to mix with the people. Guest houses were built outside the main city for the convenience of European visitors and a special quarter in the environs of Srinagar was set apart from them. Agents were appointed to look after their requirement and all business was transacted through a babu (mediator) deputed for the purpose. Throughout the course of history a corrupt and decadent rule was replaced either by the challenges of internal revolt or external aggression. The British imperialism freed the Princes from both of these dangers and the result was that they indulged in gross misgovernance. The policy of Subordinate isolation was changed in 1858 as a result of the revolt of 1857 . It was after the revolt that the British Government began to take some interest in the administration of the states. In order to safeguard the imperial interest and to take some effort towards the administrative reformation of the state, a fullfledged British Residency was established in Srinagar as late as September 1885. It was after its establishment and the subsequent intervention of the Resident that some positive changes were introduced in the administration of the state.

For a long period the state remained apathetic to provide basic medical and educational facilities to its subjects. It also remained hostile towards the
Christian missionaries, the pioneers of modern medical and educational amenities in Kashmir. It was after stiff opposition from the state the Robert Clark succeeded in opening a school at Srinagar on 18 April 1864. Such parents who sent their children to the missionary school received domiciliary visits from the police. They were told that if their children went to school they would be banished to Gilgit. Similarly Dr. Elmslie, the designated Medical doctor was not provided a space for performing his duties. Medical facilities were provided under the tress. People were not allowed to visit the doctor and sepoys were stationed around to keep them away from the basic facilities. Severeal of them suffered imprisonment for disobeying the order of officials.

The Mahraja also encouraged the contractors belonging to their own community and completely ignored the interests of the local aspirants . It is interesting to note that they invited the Hindu contractors from outside the state and offered them contracts even at the cost of the state exchequer. The state policy of pampering the non- local contractors was great factor that nursed resentment among the local Muslims. Not only outsiders were offered good positions but also were encouraged to work at the cost of locals. Number of Illegalities were imposed upon innocent people in order to suck their blood. Most of the oppressive taxes were imposed upon only Muslims and Hindus being the ruling class were exempted from the burden which pressed heavily on the Muslims. Some of the problems that were only faced by the Muslim community like, marriage tax, beggar, mandri tax, Muslim peasants were deprived of proprietary rights and ban of cow killing. All these brutal measures together later on gave birth to proper concept of freedom and ideals of justice against the existing rulers.

The people of state in order to curb the activities of rulers, a number of reformative movements were started to mobilise the sentiments of commoners against the mismanagement of harsh tempered rulers. In real sense the reformative agencies like, Ayra Kumar Sabah, Yuvak Sabha, Anjuman -i- Nusrat-ulIslam, Anjuman-i-Tahaffuzi-i-Nimaz-wa- masturat, Muslim Conference and lastly National Conference. The fundamental aim of all the socio-religious reform movements was to acquaint all the people with the reason that rulers have deliberately kept them in a state of backwardness for centuries together. All were of the belief that only good education based on western lines, supported by wise religious teachings 
would produce young Kashmiris of capacity and character.

All the movements had fully realized the importance of education and worked together for its dissemination among the people of the state in general and those of the Muslims in particular. The scarcity of schools, the absence of teachers in educational institutions and lack of financial support to educational institutions was the biggest hurdle in the development of educational system. They also had realized the significance of the female education and therefore attached considerable importance to it. The leaders were very much particular about the educational development of the state. Not surprisingly the demand of educational reformation became the main among demands made by the leadership. In the field of education our state was most backward in the whole of India and those who could merely read and write were just four percent of the total population. In spite of such educational backwardness the ggovernment spent very less on this sector as compared to Punjab. It spent only five per cent whereas the Punjab government spent fourteen percent of its total revenue on education. With the little bit progress in the said sector the seed of awareness got cropped up among the people. Although it was very late and not earlier than twenties of the twentieth century that the signs of consciousness against the dictatorial and oppressive Dogra Raj started in Kashmir.

Historically and politically it was, 13th July 1931 the most important day in the annals of contemporary Kashmir. From this day the struggle for freedom in the most modern sense started openly. The incident of 13 July shocked the whole state including the administration. The arrest of the Muslim representatives soon after the Jail incident added fuel to the sentiments which held the people in its grip. The episode gave birth to the beginning of the gigantic force behind the mass movement. However it was after 1932 that this general awareness blossomed into the formation of the first known political organization of Kashmir, All Jammu \& Kashmir Muslim conference, which was destined to play an important role in changing the pattern of Dogra rule. No doubt the name of the conference was later changed to National Conference in, 1939 under the leadership of Sheikh Mohammed Abdullah, to practically demonstrate the open- mindedness of the Muslim leadership and to involve all the people of the state irrespective of caste, colour and creed to fight for common issues. But the basis of this Hindu- Muslim courtship and the programme of the National conference lay in the nature and character of Muslim conference . They achieved their goal of New Kashmir only when they got united against the mismanagement of Dogra rulers. The main reason behind their success was the positive leadership of that time. As success is always achieved while using the right techniques and the best one was mobilisation of sentiments of people.

For the masses and workers, New Kashmir was nothing more than a simply changed Kashmir but for conscious people it was a long awaited dream. Both these views rightist and leftist within the National Conference, admit that New Kashmir programme was a revolutionary concept, a progressive Ideology and a radical philosophy. However, New Kashmir Plan was the result of the middle class leadership who had been battling against the feudal-cum -aristocratic, socioeconomic and political system in order to capture the power. Even the role and capture of power by the middle class is supported by Marx and Lenin whose theories and concepts brought about great revolutions in the world history. It was exactly in this sense that National Conference broadened the scope of movement by means of giving to it a well ideologically oriented programme in the form of New Kashmir Plan, that ultimately worked very well in realising the dream of people and they succeeded in freeing themselves from the screws of Dogras.

\section{Conclusion}

The oppressive rule of Dogras actually strengthened the very internal base of revolt. The revolutionary class comprised of all sections of society, especially the peasantry section. Although people were in problems, but still they managed to defeat them and the demand of common masses got realized only when they stand united with a one voice.

\section{References :}

1) G.M. Rabbani,Kashmir Social and Cultural History,Delhi 1986,pp.99-100

2) M. Ishaq Khan, Perspective on Kashmir, Srinagar, 1983,p.47.

3) G.M.D. Sufi, Islamic Culture in Kashmir, Delhi, 1979, p.279.

4) Baron Hugel, Travels in Kashmir and Punjab,English Translation, p.220 . 
5) G.H.Khan,Freedom Movement in Kashmir,Delhi, 1980,p.19.

6) G.M.D. Sofi, Kashir, vol.iii, New Delhi, 1974,p.395.

7) Archaeological Survey Report of 19061907,p.161.

8) Lawrence W, The Valley of Kashmir, Srinagar, 1967,p.16.

9) Muhammad Yousuf Saraf, Kashmiris Fight for Freedom, vol.1.p,441.

10) Prem Nath Bazaz, The History of Struggle for Freedom in Kashmir,p.164.

11) Shaikh Muhammad Abdullah, Atish-i-Chinar, Srinagar,pp.227-228.

12) U.K.Zutshi, Emergence of Political Awakening in Kashmir,New Delhi 1986, P.19.

13) F.M. Hassnain, British Policy Towards Kashmir, 1846-1921,P.17.

14) Mohammad din Fouq,Tarikhi Aqwami Kashmir,1978,pp.232-33.

15) Mohammad Saleem Khan,Medieval Kashmir, Srinagar, 2006, pp. 232-33. 